Financial Statistical Journal (2018) Volume 1

doi:10.24294/fsj.v1i3.574

\title{
The use of haver analytics in the case of measure economic growth WOLNIAK Radoslaw ${ }^{1 *}$, GREBSKI Michalene Eva ${ }^{2}$
}

${ }^{1}$ Silesian University of Technology, Organization and Management Department, Zabrze, Poland,rwolnia@polsl.pl

${ }^{2}$ Northampton Community College - Monroe Campus, USA

ABSTRACT
This publication presents the results of the comparative analysis of economic growth in the United States and
Poland using Harver Analytics. It takes into account factors such as GDP, industrial output, consumption expenditure,
investment, exports and consumption expenditure of the government. The aim of the publication is presentation of
differences between economic growth in Poland and USA.
Keywords: Economic Growth; Innovation; Management Tools; GDP; Production

\section{Introduction}

Since the 1950's, the United States (US) have invested in start-up companies in business incubator centers. This paper will present the wide range of criteria which are used to measure and to stimulate the economic growth of start-up companies within Poland and the United States. The aim of the paper is to analyse and compare economic growth in Poland and United States in Poland and in USA using Harver Analytics Tool.

\section{Materials and methods}

Haver Analytics, a premier provider of time sensitive data for the global strategy and research community, has been chosen to define eight methods for measuring economic growth in the Euro Area (including Poland) and the United States (US). In the US, Haver Analytics' eight output indicators to measure are economic growth are as follows (Incubator; 2017; Knopp 2007; Grebski and Wolniak 2017; Wolniak and Grebski 2017):

- gross domestic product,

- industrial production,

- unemployment rate,

- gross domestic product growth,

- personal consumption expenditures,

- investment and inventories,

- net exports of goods and services,

- government consumption and investment.

In the Euro Area (including Poland), the indicators vary slightly (Michna and Kmieciak 2012; Brzóska 2012; Rydarowska-Kurzbauer 2016; Rydarowska-Kurzbauer 2015; Pałucha 2015; Pacana et all 2016; Lew et all 2017). They include the following:

- gross domestic product,

- industrial production

- unemployment rate,

- consumer price index,

- private consumption expenditures,

- investments and inventories.

- net exports of goods and services,

- government consumption expenditures (Patterns 2017, HaverAnalysics 2017).

Copyright (C) 2018 WOLNIAK Radosław et al.

doi: $10.24294 /$ fsj.v1i3.574

EnPress Publisher LLC.This work is licensed under the Creative Commons Attribution-NonCommercial 4.0 International License (CC BY-NC 4.0).

http://creativecommons.org/licenses/ by/4.0/ 


\section{Results and discussion}

Gross Domestic Product (GDP) is the total value of goods produced and services provided in a country for one year. GDP as compared with gross national product (GNP) is more than the combined gross domestic product (GDP) of 150 nations. This information is also used to estimate the gross domestic product (GDP) per region. GDP as defined by the Business Economics Association is the total value of final goods and services (table 1). his information is also used to estimate the gross domestic product (GDP) per region. GDP as defined by the Business Economics Association is the total value of final goods and services (Gross domestic product 2017).

\begin{tabular}{l} 
Euro Area \\
\begin{tabular}{|l|l|l|l|l|l|}
\hline $3 \%$ & & & & & \\
\hline $2 \%$ & & & & 2.00 & \\
\hline $1 \%$ & & 1.95 & 1.25 & & 1.70 \\
\hline $0 \%$ & & & & & \\
\hline$-1 \%$ & -1.25 & & & & \\
\hline
\end{tabular} \\
\hline
\end{tabular}

\begin{tabular}{l} 
United States \\
\begin{tabular}{|l|l|l|l|l|l|}
\hline $3 \%$ & & & & & \\
\hline $2 \%$ & & 2,50 & 2.50 & & \\
\hline $1 \%$ & 1.40 & & & 1.90 & 1.70 \\
\hline $0 \%$ & & & & & \\
\hline$-1 \%$ & & & & & \\
\hline
\end{tabular} \\
\hline \multicolumn{7}{|c|}{2013} & $\begin{array}{c}2014 \\
\text { Source: Haver Analytics. }\end{array}$
\end{tabular}

Table 1. Comparison of gross domestic product between Euro Area and the United States. (Percent change over previous year levels.)

The Gross Domestic Product (GDP) growth for 2015 shows that Euro Area (Poland) maintained an even level at approximately $1.7 \%$ while the United States dropped below $1.5 \%$ before rebounding to $1.7 \%$.

In recent years, the United States economy averaged around 3\% growth. GDP was measured by the following five criteria (informationstation 2017):

1. rise in labor participation,

(hovers around $63 \%$ which is a 40 year low)

2. discovery of new resources.

(oil, lumber and natural gas due to fracking)

3. increase in labor specialization.

(more human capital, skills, general knowledge, and educational reform)

4. new technology/innovation (Wolniak 2013; Wolniak 20147, Wolniak and Skotnicka-Zasadzień 2014;Krzemień and Wolniak 2017),

5. increased trade.

(reducing regulations, tax policies, trade restrictions.

Industrial Production is the action of making/manufacturing from components/raw materials, or the process of being so manufactured as characterized by industry. It is also defined as the measure of output of an industrial sector within the economy, such as manufacturing, mining, and utilities. Although these sectors contribute only a small portion of gross domestic product (GDP), they are highly sensitive to interest rates and consumer demand. A comparison of industrial production was difficult because Euro Area industrial production was indexed while the United States' 
industrial production was measured in percentage change.

Production levels measured by gross domestic product (GDP) is the total dollar value of the goods and services produced in a year which in turn leads to job creation and more employment (table 2) (Production 2017).

Euro Area

\begin{tabular}{|l|l|l|l|l|l|}
\hline $6 \%$ & & & & $6.00 \%$ & \\
\hline $5 \%$ & & & & & \\
\hline $4 \%$ & & & & & $4.8 \%$ \\
\hline $3 \%$ & & & & & \\
\hline $2 \%$ & & & $2.1 \%$ & & \\
\hline $1 \%$ & & $1.9 \%$ & & & \\
\hline $0 \%$ & & & & & \\
\hline$-1 \%$ & $0.75 \%$ & & & & \\
\hline
\end{tabular}

\section{United States}

\begin{tabular}{|l|l|l|l|l|l|}
\hline $6 \%$ & & & & & \\
\hline $5 \%$ & & & & & \\
\hline $4 \%$ & & & & & \\
\hline $3 \%$ & & & $3.9 \%$ & & \\
\hline $2 \%$ & & & & & \\
\hline $1 \%$ & $1.9 \%$ & $1.9 \%$ & & & \\
\hline $0 \%$ & & & & & $-0.5 \%$ \\
\hline$-1 \%$ & $2013 \quad \begin{array}{c}2014 \\
\text { Source: Haver Analytics }\end{array}$ & $-2.0 \%$ & $2016\left(1^{\text {st }} \mathrm{2}\right.$ \\
\hline \multicolumn{7}{|c|}{$2016\left(3^{\text {rd }} \mathrm{Q}\right)$} \\
\hline
\end{tabular}

Table 2. Comparison of industrial production between Euro Area and the United States, 2013-2017 using percentage points.

There were very dynamic changes within any given year. In many years, the changes did not show such dynamic changes. A closer look at the data shows major difference in industrial production between the Euro Area and the United States. In some cases, the data would need to be analyzed month-by-month. Industrial production as a measure of economic growth needs to be analyzed in both the short term and the longer term.

Private/Personal Consumption Expenditures (PCE), or the PCE Index measures price changes of consumer goods and services (Hąbek and Wolniak 2016a, Hąbek and Wolniak 2016b). Expenditures noted on the index include actual expenditures and expenditures that are attributed to households in the United States. Data that pertains to services, durables and non-durables is measured through the index. Sharing similarities with the Consumer Price Index (CPI), the PCE is part of the personal income report issued by the Bureau of Economic Analysis of the Department of Commerce. The definition of consumption is simply the action of using up a resource (table 3) (Investopedia 2017).

\begin{tabular}{l} 
Euro Area \\
\begin{tabular}{|l|l|l|l|l|l|}
\hline $3 \%$ & & & & & \\
\hline $2 \%$ & & & & & \\
\hline $1 \%$ & & & $1.00 \%$ & $1.50 \%$ & \\
\hline $0 \%$ & & $0.50 \%$ & & & $0.80 \%$ \\
\hline$-1 \%$ & $-0.50 \%$ & & & & \\
\hline
\end{tabular} \\
\hline
\end{tabular}




\section{United States}

\begin{tabular}{|l|l|l|l|l|l|}
\hline $3 \%$ & & & $3.00 \%$ & & \\
\hline $2 \%$ & & $2,25 \%$ & & & $2.00 \%$ \\
\hline $1 \%$ & $1.25 \%$ & & & $1.75 \%$ & \\
\hline $0 \%$ & & & & & \\
\hline$-1 \%$ & $2013 \quad 2014 \quad \begin{array}{c}2015 \\
\text { Source: Haver Analytics }\end{array}$ \\
\hline
\end{tabular}

Table 3. Comparison of personal/private consumption expenditures for the Euro Area and the United States, 2013-2016 using percentage points.

The 3rd Quarter of Private/Personal Consumption in Euro Area (Poland) rose slightly after a significant gain in the 1st Quarter and a sharp drop in the 2nd Quarter. Meanwhile, the USA had a slight drop in the 3rd Quarter after consecutive drops in 2015 and a slight drop in the 1st Quarter of 2016. There was a significant rise in personal consumption expenditures in the 2nd Quarter of 2106.

Investment can be considered from three different perspectives. It can be either the action or process of investing money for profit, a thing that is worth buying because it may be profitable or useful in the future or an act of devoting time, effort, or energy to a particular undertaking with the expectation of a worthwhile result. Inventory (from an accounting perspective) is the entire stock of a business, including materials, components, work in progress, and finished product. Inventory is the investment in raw materials, work in progress and finished stock.

In contrast with fixed investment, inventories are constantly being turned over as the production cycle repeats itself, withdraw materials being purchased, converting these materials from work in progress into finished goods and sold as products. The level of inventory and investment can result in an unsold goods build up or a decline of demand. Expectations are not met and inventory must be depleted (table 4). Firms use investment and inventory as a factor to measure economic growth (Investment 2017).

\section{Euro Area}

\begin{tabular}{|l|l|l|l|l|l|}
\hline $3 \%$ & & & & & \\
\hline $2 \%$ & & & & & \\
\hline $1 \%$ & & $1.75 \%$ & $1.00 \%$ & & \\
\hline $0 \%$ & & & & $-0.40 \%$ & $0.60 \%^{*}$ \\
\hline$-1 \%$ & $-1.25 \%$ & & & & \\
\hline$-2 \%$ & & & & & \\
\hline \multicolumn{7}{|c|}{2013} & 2014 & $2015 \quad 2016\left(1^{\text {st }} \mathrm{Q}\right)$ & $2016\left(3^{\text {rd }} \mathrm{Q}\right)$ \\
\hline
\end{tabular}

\section{United States}

\begin{tabular}{|l|l|l|l|l|l|}
\hline $3 \%$ & & & & & \\
\hline $2 \%$ & $2 \%$ & & & & \\
\hline $1 \%$ & & & $1.75 \%$ & & \\
\hline $0 \%$ & & $-1 \%$ & & $-0.40 \%$ & $0.50 \%$ \\
\hline$-1 \%$ & $2013 \quad \begin{array}{c}2014 \\
\text { Source: Haver Analytics }\end{array}$ \\
\hline$-2 \%$ & & & & \\
\hline \multicolumn{5}{|c|}{$2015\left(1^{\text {st }} \mathrm{Q}\right)$} & $2017\left(3^{\text {rd }} \mathrm{Q}\right)$ \\
\hline
\end{tabular}

Table 4. Comparison of investment and inventories between the Euro Area and the United States, 2013-2017 using percentage points.

Investments and inventories showed a dramatic contrast between Euro Area (Poland) and the USA. Euro Area 
(Poland) ended the 4th Quarter of 2015 at approximately 2\% while the United States percentage points dropped below $0 \%$ and remained at negative percentages until the 3rd Quarter of 2016.

Net Exports of Goods and Services are the difference between a country's total value of exports and total value of imports. Depending on whether a country imports more goods or exports more goods, net exports can be a positive or negative value. An export can be defined as the selling and sending out of goods or services to other countries (table 5).

Net exports of goods and services were positive in the Euro Area (Poland) until the 3rd Quarter of 2016 with a $0.3 \%$ loss. In the meantime, the USA rebounded in the first three quarters of 2016.

Euro Area

(Percentage points)

\begin{tabular}{|l|l|l|l|l|l|}
\hline $3 \%$ & & & & & \\
\hline $2 \%$ & & & & & \\
\hline $1 \%$ & & & $1 \%$ & & \\
\hline $0 \%$ & $0.50 \%$ & $-0.75 \%$ & & $0.60 \%$ & $-0.30 \% *$ \\
\hline$-1 \%$ & & & & & \\
\hline$-2 \%$ & & & & & \\
\hline
\end{tabular}

United States

(Percentage points)

\begin{tabular}{|l|l|l|l|l|l|}
\hline $3 \%$ & & & & & \\
\hline $2 \%$ & & & & & \\
\hline $1 \%$ & & $1.25 \%$ & & & \\
\hline $0 \%$ & $0.30 \%$ & & & $0 \%$ & $0.80 \%{ }^{*}$ \\
\hline$-1 \%$ & & $-1.80 \%$ & & \\
\hline$-2 \%$ & 2013 & $\begin{array}{c}2014 \\
\text { Source: Haver Analytics. }\end{array}$ & $2016(1 \mathrm{stQ}) \quad 2016\left(3^{\text {rd }} \mathrm{Q}\right)$ \\
\hline
\end{tabular}

Table 5. Comparison of net exports of goods and services between Euro Area and United States, 2013-2017

\section{Conclusion}

In summary, the latest output indicators (February 27, 2017) for measuring economic growth in Poland and the United States show the most significant difference in unemployment data. Industrial production was not measured in January 2017, so there is no comparison for this indicator (Table 6).

\begin{tabular}{|l|l|l|}
\hline Output Indicators & Poland & United States \\
\hline GDP (change on a year ago) & & \\
\hline Latest & $+2.3 \mathrm{Q} 3$ & $+1.9 \mathrm{Q} 4$ \\
\hline Quarter & +7.0 & +1.9 \\
\hline 2016 & +2.8 & +1.6 \\
\hline 2017 & +3.2 & +2.2 \\
\hline & & \\
\hline Industrial Production & & \\
\hline Latest & +9.0 (January) & Not available for January \\
\hline & & \\
\hline Consumer Prices & & \\
\hline Year ago & -0.9 & +1.4 \\
\hline
\end{tabular}




\begin{tabular}{|l|l|l|}
\hline 2016 & -0.7 & +1.3 \\
\hline & & \\
\hline Unemployment & 8.6 (January) & 4.8 (January) \\
\hline
\end{tabular}

Source: Author's analysis.

Table 6. Summary of Poland and United States methods of measuring indicators of economic growth: 2016-2017.[2.15]

\section{References}

1. Brzóska J. W kierunkuwzrostuwartościorganizacjiWybraneaplikacje BSC,

ZeszytyNaukowePolitechnikiŚląskiej.Seria Organizacja i Zarządzanie 2012; (60): 27-47.

2. financial-dictionary. the free dictionary.com/inventory+investment [DOA: 02.14.2017].

3. Grebski ME, Wolniak R. Building an ecosystem for economic growth, "KwartalnikNaukowy Organizacja i Zarządzanie”, Kwartalnik Organizacja i Zarządzanie" 2017; (3): 5-20.

4. Hąbek P, Wolniak R.: Assessing the quality of corporate social responsibility reports: the case of reporting practices in selected European Union member states. Quality \&amp; Quantity 2016; 50(1): 339-420.

5. Hąbek P, Wolniak R. Factors influencing the development of CSR reporting practices: experts' versus preparers' points of view. Engineering Economy 2016; 26(5): 560-570.

6. Haver Analytics, haver.com/databaseprofiles.html [DOA: 02. 14. 2017].

7. http://www.ecb.europa.eu/pub/other/art1_mb20110.en.pdf., pp. 70-72,76 [DOA: 02.14.2017];

8. http://www.investopedia.com/terms/p/pce.asp\#ixzz4bJbDPMe3;[DOA:02.14.2017].

9. https://en.oxforddictionaries.com/definition/consumption [DOA:05.31.2017].

10. https://en.oxforddictionaries.com/definition/gross_domestic_product,[DOA:05.31.2017].

11. https://en.oxforddictionaries.com/definition/incubator [DOA: 05:31:2017].

12. https://en.oxforddictionaries.com/definition/inventory [DOA:05.31.2017].

13. https://en.oxforddictionaries.com/definition/investment,[DOA:05.31.2017].

14. https://en.oxforddictionaries.com/definition/production, [DOA: 05.31.2017]

15. https://en.wikipedia.org/wiki/Industrial_production [DOA: 02.14.2017].

16. https://www.bea.gov/scb/account_articles/genral/0100od.maintext.htm [DOA: 02.14.2017].

17. Knopp, L. State of the business incubation industry, athens, ohio. National Business Incubation Association 2007.

18. Krzemień E, Wolniak R. InnowacyjnośćpolskiejgospodarkinatlekrajówUniiEuropejskiej. Kwartalnik Organizacja i Zarządzanie" (4): 155-165.

19. Lew G., Pacana A., Kulpa W.: The concept of customer cost accounting. Journal of Business \&amp; Retail Management Research (JBRMR) 2017; 11(3): 124-129.

20. Michna A., Kmieciak R. Orientacjarynkowa a zarządzaniewiedzą w kontekścierozwoju i wzrostumałych i średnichprzedsiębiorstw, ZeszytyNaukowePolitechnikiŚląskiej. Seria Organizacja i Zarządzanie” 2012; (60): 203-216.

21. Pacana A, Pasternak-Malicka M, Zawada M, et al. Wspomaganiepodejmowaniadecyzji w produkcjifoliiopakowaniowejz wykorzystaniemanalizykosztowo - jakościowej, „PrzemysłChemiczny” 2016; (5).

22. Pałucha K.:Wdrażanieinnowacji w obszarzeorganizacji i zarządzaniaelementemwpływającymnawzrostkonkurencyjnościprzedsiębiorstw, ZeszytyNaukowePolitechnikiŚląskiej. Seria Organizacja i Zarządzanie” 2015; (78): 353-366.

23. Patterns of Euro Area and US Macroeconomic Cycles - What Has Been Different This Time?, ECB: Monthly Bulletin, May 2011.

24. Rydarowska-Kurzbauer J. InnowacyjnośćwybranychkrajówEuropyŚrodkowo-Wschodniej, ZeszytyNaukowePolitechnikiŚląskiej. Seria Organizacja i Zarządzanie 2015; (96): 93-101.

25. Rydarowska-Kurzbauer J.: UwarunkowaniainnowacyjnościwybranychkrajówEuropyŚrodkowo-Wschodniej, ZeszytyNaukowePolitechnikiŚląskiej. Seria Organizacja i Zarządzanie 2016; (96): 155-165.

26. Wolniak R, Grebski ME. Functioning of the business incubator center on Gliwice. ZeszytyNaukowePolitechnikiŚlaskiej. Seria Organizacja i Zarządzanie 2017; 105.

27. Wolniak R, Skotnicka-Zasadzień B. The use of value stream mapping to introduction of organizational innovation in industry. Metalurgija 2014; 53(4): 709-712.

28. Wolniak R: Metody i narzędzia Lean Production i ichrola w kształtowaniuinnowacji w przemyśle, [w:] monografii „Innowacje w zarządzaniu i inżynieriiprodukcji” [red:] R. Knosala, OficynaWydawniczaPolskiegoTowarzystwaZarządzaniaProdukcją. Opole 2013, 569-580.

29. Wolniak R.: Relationship between selected lean management tools and innovations, ZeszytyNaukowePolitechnikiŚląskiej. Seria Organizacja i Zarządzanie, z 75, 2014, s. 157-266. 